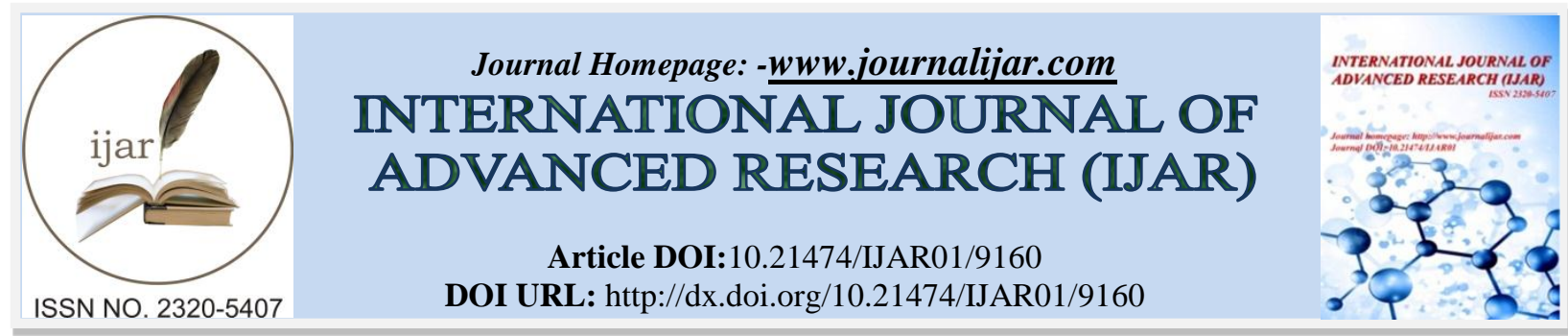

RESEARCH ARTICLE

\title{
ORAL SONGS IN THE CULTURAL RESISTANCE OF SALAALEE OROMOO.
}

\author{
Melese Ejara. \\ Mekdela Amba University (Wallo)College of Social Science and Humanities Department of History and Heritage \\ Management.
}

\section{Manuscript Info}

\section{Manuscript History}

Received: 24 March 2019

Final Accepted: 26 April 2019

Published: May 2019

Key words:-

Cultural resistance, oral songs, Salaale, poetic, folklore.

\section{Abstract}

The main objective of this paper is to collect and analyze oral songs in the Cultural resistance of Salaale Oromoo. In the history of written literature of a given society, poetic compositions constitute one of the most important elements of the literature. One of the ways in which these poetic compositions are expressed is through songs by individuals or bands. In one way or another, the songs by individual vocalists or bands express the life situation of the society. The contents of the songs might be political, economic or social. In line with this, through oral songs, the Salaale Oromo expressed how much their incorporation with Ethiopian empire brought about significant socio-economic and political changes with far reaching consequences. The researcher found that the lives of slaves were better than that of Salaale gabbar under the four distinct political systems namely: Menilik II, the imperial, the Derg and Tplf. Besides commenting on the military regime, oral songs also advised the Oromo to have patience if they wanted to use their language for public purposes. The Salaale internal migration to Arssi and Baale has been repeatedly described in their songs. In Salaale, heroes are celebrated and their deeds retold as a role model through songs and folklore. The purpose of these oral songs is to portray the extent and form of the economic subjugation of peasants. They also show the peasant protest and social critique about local official's confiscation of land, corruption and policy change. In dealing with the paper, qualitative research methods (narrative and descriptive research methods) have been used. The necessary data for this study were collected from primary and secondary sources. The data from primary sources were collected during field work. On the other hand, secondary sources relied on documents that used before and after fieldwork. As a result, the study is the product of two types of works; library and fieldwork. The main purpose of this study, hence, is to produce academic research in the cultural heart land of Salaale Oromo. Little has been done on this subject. Hence, the researcher has recommended that oral songs should be appropriately collected and recorded. Efforts should be made to preserve and maintain oral songs as cultural heritage as well as history. Studying oral songs contributes to the recording and preserving of the Oromo literatures that is part of the oral literature of the region .In such a way, it would have significance for academic

Corresponding Author:-Melese Ejara. 
research activities, general public and could advance the frontier of our knowledge on Cultural resistance of Salaale Oromo through oral songs.

Copy Right, IJAR, 2019,. All rights reserved.

\section{Introduction:-}

The Oromo are a Cushitic people who live in the East African region known as the Horn of Africa. ${ }^{1}$ The Salaale Oromoo is the Tulama branch of the Cushitic Oromo in Ethiopia inhabiting northwest of Finfinne. Because of their closeness to the Shawan Amhara Christians to the north, the Salaale lived under an uneven historical relationship. ${ }^{2}$ The people of Salaale are rich in oral literature. In his authoritative book, Wax and Gold, Donald Levine wrote that the genius of peasants is visible in the stories, songs, verses, proverbs, etc., that make up their rich oral literature. ${ }^{3}$ In Salaale, narratives and other folkloric expressions, the themes of bravery, patriotism and the pride are constantly repeated in their song. In this regard, Assefa Tefera writes the following: "The Salale songs of grievances, quuqaa, about land are typical examples of historical songs. By singing such songs as faarsa commemorative songs, full of life and ardor, the people share not only history but also a common ground and perspective". 4

The Salaale are also well known for their tradition of geerarsaa, which is the song of the brave men. Thus, the study of historical oral song and poetry is an important field of research in Oromoo literature but it has not been systematically investigated specifically on the various genres of Salaale oral song and poetry that was handed down through generations. On the other hand, the oral song and poetry of the Salaale people is an unexplored genre. One finds only a few studies in such a widespread and most functional genre. As a result of this condition, it becomes very important to study the oral songs which have long been used in the area and to preserve them in a way which would be helpful to see the people's thought, feelings, beliefs, hopes and desires as well as their way of living in general through subject matter analysis.

\section{Objectives}

\subsubsection{General objective}

The general objective of this study is to collect and analyze oral songs in the Cultural resistance of Salaale Oromoo.

\subsubsection{Specific Objectives of the Study}

The specific objectives of the study are:

1. To collect historical oral songs and poems dedicated to Salaale heroes;

2. To collect historical oral songs and poem dedicated to patriot (1935-41);

3. To analyze oral songs according to their central ideas and contexts;

4. To suggest better ways of preserving possible ways how the existing historical oral song; and poems handed down through generations.

\subsection{Significance of the study}

By carrying out a research of Oral songs in cultural resistance, the researcher hopes that this research on oral songs would:

1. It helps others to appreciate the creativity and wisdom of the community where the oral song and poetry comes from.

2. Contribute its part to the development of Ethiopia oral literature, in general,and Oromoo oral literature in particular

\footnotetext{
${ }^{1}$ Workineh Kelbessa, "Traditional Oromo Attitudes Towards the Environment an Argument for Environmentally Sound Development”,Social Science Research Report ,Series - No. 19,(Addis Ababa, 2001),p.1; see also P.T.W.Baxter,Jan Hultin and Alessundro Triulzi, "introduction" in Being and Becoming: Oromo Historical and Anthropological Enquires, (Uppsala, 1996), p.7.

I. $\quad{ }^{2}$ Assefa Tefera, "Heroes and Heretics: Performing Nationalism in Ethiopia Cushitic Salale OROMO IN NORTHEAST AFriCA”, (INDIANA UNIVERSITY, 2013; Also AVAILABLE AT ET H N O E C O L O G Y. C O M.

${ }^{3}$ Donald N.Levine, Wax and Gold: Tradition and Innovation in Ethiopian Culture, (Chicago, 1965), p.243

4 AssefaTefera, "Ethnography of Resistance Poetics: Power and Authority in Salale Oromo Folklore", (PhD. Dissertation, Folklore, Indiana University, 2015), p.56.
} 
3. Serve for other researchers, and students of the folklore and literature as reference material and point of departure for further study.

\section{Methodology:-}

\subsection{Methods of Data Collection}

The data has been collected by using primary as well as secondary sources. In order to compile out data for this research, different methods and procedures have been used as briefly discussed below. The heroic recitals employed in the study are collected using interviews, participant observation, recordings, and documents.

\subsection{Field Research}

To gather data in the field research in Salaale, interviews, observations, and recorded documents have been used. For the interview, the purposive selection is made to select elderly people who have rich knowledge of the local history and the study area. This is because a historical song is not every man's practice. It demands a gift to compose, memorize, and perform it on certain occasions with the right manner of acting. The interview is done to learn the prominent occasions and functions of heroic the song in the area.

\subsection{Observation}

Observation is made to see how people react during historical songs and to have the whole picture of the environment. These in a way help to the understanding of the meaning of the songs easily. Though the researcher did not get the chance to attend any heroic songs recited in a real context, in his four months stay in the field, he uses his experiences, and audio and video records taken in the real contexts for observation. That is to say, the researcher is from that area. He had the opportunity to see heroic songs performed at various special events. In fact, two years ago he had made his own records of heroic recitals in the real context.

\subsection{Documents}

Published and unpolished sources (books, articles, journals, theses, and others) have been utilized for the research. Most of these sources were obtained from Addis Ababa University (AAU) (Institute of Ethiopian Studies (IES).

\section{Oral Songs in Resistance of Salaale Oromo (1870s-1900s)}

There is ample evidence that the influx of Amhara into the region of Salaale brought about frequent wars and clashes, which were expressed by the widespread emergence of several rebellions. Conflict over the economy particularly between the early settlers and those who came later was one of the main reasons that contributed to the rise of Bulloo Galgal, Ashee Ruufoo, and Goshuu Gissillaa. ${ }^{5}$

The local community for his resistance against Ras Daargee has remembered Bulloo Galgal. ${ }^{6}$ The conflict was said to have occurred when Ras Daargee ordered his servants to cut down the waddessa (juniper) of Bullo Galgal from his ritual place to construct Fiche Gannat Georgis Church. According to Wakene Frew, until 1900, there were more than 374 churches established between 1800-1900 in Korra -Merabite, Kuyyuu-Aboote, Midda, Insaro, Wuchale, Girar Jaarsoo, Debralibanos, Darra and Gullale. The neighboring Oromo also strongly challenged the establishment of these early churches because the churches were built near or at the Oromo ritual and political center. ${ }^{7}$ Their firm resistance and strength remembered well in tradition as follows:

\section{Afaan Oromoo}

Baddessan Bulloo Galgal

Lola Daargee dhalchee

Gaafa Goshuun

Hin Gabbaruu jedhee lole

Daargeen Ashkaree

Nurratti dhalche

\author{
Gloss \\ ritual and political site of baddeesaa Bulloo Galgal \\ brought the war against Ras Darge \\ when Goshuu \\ denied the order of Daargee \\ Daargee who bornt \\ slaves on the land of Salaale. ${ }^{8}$
}

\footnotetext{
${ }^{5}$ Informants: Kabbe Yaadee Abarraa Gammadaa, Gimjaa Gonfa Abebe Bayu and Kabbee Gissilaa.

${ }^{6}$ Informants: Shitaaye Kabbee, Ejaaraa Damee and Iseeyii Taddassaa.

${ }^{7}$ Wakene Frew, "The Family of Ras Darge and Church in Salale", (BA.Thesis, History, Adds Abbaba University, 1973), p.28.

${ }^{8}$ Informants: Kabbee and Mammoo.
} 
In some instances, the Oromo around Salaale did actually chase priests and threatened them in several times. That is why it came to be said essarraan araara buftii qeesiin garaadhaf duuti. Literally means priest cannot bring peace rather than dying for food. It was during the expansion of kiristinaa (baptism) in Salaale, the local populations of the area sang a warning song against Ras Daargee as follows:

\section{Afaan Oromoo}

Gattiraan baalaa

Baalatu muka

Kiristinnaan maalii

Yaa Daargee dubbadhu dhugaa
Gloss

Juniper is a leaf

leafs can be a tree

what is the meaning of being Christian?

you Daargee speak truth. ${ }^{9}$

As oral tradition indicates when Ras Daargee encountered with Goshuu Gissila (the local chief of Salaale) in 1870s, Daargee came up with "negarit” (literally, drum) and said to Goshuu 7 nद " $)$. Then Goshuu responded in his mother tongue: "hin gabbaru; hin gabbaru”. This literally means, "I never pay any kind of tribute to you" neither in cash nor in-kind.

Following his refusal, Daargee ordered him to construct the gibbii (palace) at Fiche. When Goshu presented the issue for the public, they responded better to die than to cut trees and construct the palace. Hence, these factors made Goshuu Gissilla to be fugitive, particularly in the area covered with dense forest and surrounded by foothill so-called Darroo Birbisa Goshuu. ${ }^{10}$ In Line with this, Alemseged asserts that Goshu took refuge in a cave to live with wild animals than submit to enemies. ${ }^{11}$ Their conflict came to end when Daargee's armed forces exiled to Hawaxo to capture Goshu's force. Goshuu died at Botor and buried at Faalloo Mikael in Gindabarat. ${ }^{12}$ It was during the course of struggle; Goshuu Gissillaa produced the following poem:

\section{Afaan Oromoo}

Jabana koo fardaa lafaa lolee tanan Dadhuma dhugee garuma bulee Jabanni kee gandaan na labe yaa Birruu

\section{Gloss}

during my reign I fought with infantry and cavalry I drink honey wine and I lived luxurious life You Birru, your reign filled me with instability, chaos.

Similarly, Assefa Teffara collected sang a song that commemorates Goshu for his heroic endurance as a bandit:

\section{Afaan Oromoo}

Goshuu Gissillaa

Tabataa qawweedhaa

Hin gabbaru jedhee

Waashaatti gale

Dabbaallii jawweedhaa! ${ }^{13}$

\section{Gloss}

Goshu Gissillaa, the fearless

who played games with gun,

repelled subjugation,

andtook refuge in the cave

share a room with a python!.

\subsection{Some Historical Oral Song of the Salaale from (1935-1941)}

According to many studies, the occupation of Italy regarded as liberation when compared with the former exploitation of the people by feudal lords. This might be true for the poor Oromo tenants and gabbars because the Italians were abolished free labor service. ${ }^{14}$ Because of this, the Italians appreciated among the Oromo as tola faraanjit balleesse (the feranj eliminated free service). ${ }^{15}$ Sources indicate that many Oromos' did not resist the occupation of Italy between the years 1935-1941). However, in Salaale the situation is reverse. This might be true in Tekletsadiq Mekuria work that Shewa was a double of Gojjam and Gondar in the aspect of the patriotic

\footnotetext{
${ }^{9}$ Informants: Sanbatuu Iraasuu, Dachaasa Waari, Asaffaa Nugusee, and Gonfaa.

${ }^{10}$ Informants: Kabbee, Dassee Kabbaaba and Kabbee Gissila.

${ }^{11}$ Alemseged Debele; "A History of Kuyyu, 1936-1991”, (MA. Thesis, History, Addis Ababa University, 2010),p.24.

12 Informants: Ibid.

${ }^{13}$ Assefa, p.333.

${ }^{14}$ Taddesse Berrisso, "The Pride of The Guji-Ommo:An Essay On Cultural Contact And Self-Esteem”, in The Journal of Oromo Studies Volume 11, Numbers 1 And 2, (2004),p.19; See also Biratu Kenei,."A History of Oromo in and Around Finfinne (Addis Ababa)From Ca 1860-1974”,M.A. Thesis, History ,Addis Ababa University, 2010, p.77.

${ }^{15}$ Biratu,p.88.
} 
resistance ${ }^{16}$. That is why Salaale people hand over through reminiscence by means of the following song in Afaan Oromoo word:

Maqale yaa maqalee biyya shawaan itti qalame-- Oh Mekele Mekele the city where the Shawns' were murdered Kan du'e du'ee kan hafe gale -- while many were killed, the remaining came back to their homeland ${ }^{17}$

Like other portion of Ethiopia, in Salaale, many heroes have been struggled against the fascist occupation from different corners of the region under study. The well-known personalities during the five years of Italian occupation who bravely fought in Salaale were Dejjach Geleta Koricho, Fitwerari Mulu Asanu, Kegnasmach Belachow Asanu and Lammi Hata'u (the father of Assefa Sharoo Lammii). In the course of their resistance against Italian invasion (1936-1941), Mulu Asanu in collaboration with other patriotic "organized the Salaalee Oromo [under a warrior name] Mata Goraa. They fought several battles .To mention a few of them, Kararu, Bondi, Dugda Dhera, Wajju, Midda, Maranya Abbo, Danguuree, Gafichi Abbo, Qabena, Faxira, Meskel Sefar, Morat, Adare, Mosibit Amba and Gobil were the well-known battlefield. ${ }^{18}$

In their occupation, the Italians found a few collaborators from some woradas of Salaale. ${ }^{19}$ The one well-known initial collaborator in Salaale was Dajachmach Demise Ingida who was born in Gojjam particularly at a place called Merto-lemariyam. The coming of Italians helped Demise Ingida to stay on his position. He joined the Italians in 1936 and remained loyal to them throughout their occupation.

It was during that time, the local residents of Wajju narrate the following poem, which implies a critique of Wajju people against collaborators as follows:

\section{In Afaan Oromoo word:}

Mogor Keessattin argee gootaara jirbii gootaara jirbii

Wajjunan lola jedhet Ejjersati dhume wanumti Girmii

Yaa Damissee Ingidaa sumatu fide idaa

Siin jetti ijoolleen midaa

\section{When translated to English}

I saw the granary of cotton in Mogor

The Girmi people were executed at Ejersa while confronting with wajju

Oh, Demise Dngida you yourself brought the risk

Said the clan of Midaa (the subclan of Wajju) ${ }^{20}$

Yeroo Waajju bu'ani While marching towards Waajjuu

Yaa cirracha isaa (2 xs) there are a number of sands

Yeroo Damisseen du'ee if Demissie died his ribs be the food of birds

Nyaadhu yaa allaacha cinaacha isaa. ${ }^{21}$

Karaa Shaggar

Yaa karaa sallaattoon barreessite

Dhageechee yaa Abarraa

Biyya kee sallaattoon (Italians) balleesite the high way of Shagar

the road which constructed by Italians

have you heard Abarraa

Italians destroyed your country. ${ }^{22}$

\subsection{Salaalee Oral Songs After 1941}

According to tradition we have collected from Salaale, after the evacuation of Italians, some people had received maderia land and continued to use it until the revolution in 1974. On the other hand, there were individuals who had taken part in the war of liberation but remained without being reward maderya land. Similarly, Alemseged states that like other ordinary men, most of them have remained with the title of Obbo (mister).Unlike other patriots of

\footnotetext{
16 Tekletsadiq Mekuria, yee Ethiopia Tarik Kaa Atse Tewodros eska...p. 307-310;Pawlos Nogno yaityopya-na yaxalya torenat (Addis ababa 1980 e.c)p,240-256.

17 Informant: Ijaaraa Damee and Gergisoo Damee

${ }^{18}$ Informants:Ababa, Biraanuu Tassamma, Caaltu Baloo and Caaltuu Baloo

${ }^{19}$ Informant:Kabbe Gissila and Kabbe Yadee

${ }^{20}$ Ibid

${ }^{21}$ Informants:Iseeyi Taddassa, Gonfaa Kabbabaa and Galaan Yeshaanaw

22 Informants: Biraanuu Tasammaa and Zawudee Gonfaa.
} 
Ethiopia, many of Oromo in Salaale did not get the necessary recognition for their contribution. ${ }^{23}$ This situation led to the rise of many shiftas' (bandits') throughout the 1940s for the reason that they were participated in the war of liberation but remained without acquiring maderia land. During this time, the local governor of Salaale was Dajjach Demise Segu, son- in -low of Ras Kassa.

As is evident from the next song, the local people became victims of government violence than the bandits' male violence. This is because the Waajjuu peoples never condemned social banditries for the reason that they were well aware as it was for economic and political emancipation. They condemned Demise Segu as follows:

\section{Afaan Oromoo}

Damissee Sagguu

Soddaa warra iraasi

Iraastu ajeejee

nu dhaane jarjjaree

Gullallee immo maaltu ajeejee

Nu saame barbaaree

Yaa Damissee Sagguu

Gurraacha qoma leellee

Otoo Balee Abbaa Giddii jiraatee

Muzgeerin si haleele. ${ }^{24}$

\section{Gloss}

you Demise Segu

the son in law of Ras Kasa

he was Ras Kasa

who ordered him to assault or beat us

And what ordered the Gullallee

to rob our pepper?

You Demise Segu

the very black man

if Balachew Abbaa Giddii was alive

you would be attacked by muziger.

During the imperial regime, the gabbar cultivated the Kudad (hudad) and delivered the entire crop to landlord. It was tetari or Zagi who collected one third of the produce from gabbars land as a tribute for landlord, and another tenth to the state as tithe. ${ }^{25}$ The peasants of the area worked one day for ploughs, one day for sowing, and two days for weeding and two days for gathering the harvest per year. Informants unanimously agreed that the major source of this problem was zagii or tetari. The tetari or zagii elected from gabbars to serve as intermediaries between balabat and the gabbar. Zagii or tetari either guess the crops standing on the field or collected before threshing based on their relationship with gabbar. Most importantly, it was during that time, the local people of Salaale produced poems to disapprove zagii or Tetatri as follows:

Afaan oromoo
Abbaan Lafaa maal nu ballesse
Kan nu ballesse taxaridha
Yaa taxari mila kaboota
Kanarra maaluma nu gootaa
Bishaan qarssaara gadi yaa'u
Yaa taxaari
Yaa ilma haadha gadi raawuu. ${ }^{26}$

Afaan oromoo

Kan nu ballesse taxaridha

Yaa taxari mila kaboota

Kanarra maaluma nu gootaa

Yaa taxaari

Yaa ilma haadha gadi raawuu. ${ }^{26}$

\author{
Gloss \\ landlord didn't harm us \\ but it was the viceroy of the landlord who harmed us \\ You the viceroy, a man with sprawled leg \\ you could not do anything than this \\ the river flows on the surface of the rock \\ you the viceroy \\ you an idiot man.
}

The torturing rude word"ilma haadha raawu", sadly demonstrates some deep-rooted hateful social order in Salaale. In addition to this, Dachasa also collected oral songs concerning to the maladministration of the people under the agent of zagii (the mediator of landlord).

Biyya taa'uuf zagituu hammatee

Lagga Gibee busaatu hamatee

Biyya kafaa karaatu fagaatee

Kan Iyyeessaa rakkinuma taatee. ${ }^{27}$ to live in my village the agent is wicked

to cross the Gibé River malaria is hostile

to go to Kafa it is too far

for the poor it is too problematic.

From the above proverbs, it seems that the peasant feared disease resulted from malaria in the Gibe region. In Salaale, more than others, Amdee Abarraa evicted the people from their land to Arssi and Baale. One of our informants evicted from his land tell us: "we are displaced soon, our grazing land and farming land has been taken

\footnotetext{
${ }^{23}$ Alemsegad, p.33.

${ }^{24}$ Informants: Kabbee, Mammoo,Dachaasa, Melaku Tafarraa

${ }^{25}$ Informants: Gonfaa, Habtamuu Sanbataa, Mammoo and Ijaaraa.

${ }^{26}$ Informants: Dachaasaa,Damise Mokkonnon and Hundee Tulluu.

${ }^{27}$ Dechasa Abebe, “A Socio-Economic History of North Shewa, Ethiopia (1880s-1935)”, (PhD. Dissertation, History, University of South Africa, 2015), p.251.
} 
by Amde Abara for rearing domestic animals and it seems that the animals are more important than us." When the Shewan Amhara rulers appropriated their land, the Salaale sang as follows:

Ati yaa Amdee Abarraa

Maaf qotte maasaa lagarraa

Silaa hiyyeessa fixxee lafarraa

Si haa gaafatu ayyaanni warraa!. ${ }^{28}$

Abbaa lafaa yaa bara beekaa

Gatiin kaloo barana meqaa

Kan durrati Birrii sadeeti

Barana immo dhibba sadeeti

Hintane kaa ulee waliirra keenyaa

Kan bahu Birrin Keenyaa. ${ }^{29}$ you, Amde Abara

why you cultivated the arable farm lying on the waterway

you dislocate the poor

May their ancestral spirit judge you and penalize you.

You the landlord who knows the rule

How much is the price of hay this year?

it was merely eight Birr in the past

it skyrocketed to 800 Birr this year

it is unfair, we will see each other raising our stick

the fine from our asset.

Informants claim that the lives of slaves were better than that of Salaale gabbar because the slaves work for his landlord who at least feeds him whereas gabbar vice versa. ${ }^{30}$ It was during that time the local Oromo of the area expressed the change that happened to them. The song is expressed in the following way:

\section{Afaan Oromoo}

Akka jedhe qottuun qotiyyoo

Qoteen orma nyaachisa

Dhaheen orma ilaalchisaa

Abet yaa jiruu Salaale

Jiruun too akkana taatee

Hooloota sardiidni nyaate

Garbuu jaldessatu nyaate

Jaldessi maal na balleesse

Anatu ofirratti goobsee. ${ }^{31}$

\section{Gloss}

as the farmer plowing with ox states

I plow and fed the alien (the landlords)

I thresh the crops and made my yield to be seen by alien

Oh the miserable life of Salaale

the fate of my life is like this

the sheep were eaten byfox (landlords)

barely was eaten by monkeys

monkey has done nothing to me

it is I myself that elevated them to this position.

What is important to know from the above song is that the peasant sang not to accuse animals instead it was deliberately aimed to show how much they were exploited by feudal administrative system.

\section{Afaan Oromoo}

Atoobisin Baale ilaalee

Ana jiruun natti hin taanee

Nagaati yaa biyya abbaa koo

Jette ijoollen Salaale

Siif ba'e biyyaa sif ba'e

Yoo sardidni irboo sif hire

Yoo hadaan olla siif ta'e

Yoo Jaldeessi ciisii sif tahe

Yoo mujjaan midhaan siif ta'e

Siif ka'ee biyyaa siif ka'ee. ${ }^{32}$

\section{Gloss}

the car will travel to Bale

I unable to bear any more burdens

Good by my father's land

said the youth tenants of Salaale

you the landlord, I left my land for you, here it is

if foxes share a quarter for you

If the plants being your neighbors

if the monkeys become tenants for you

if grass family renders grains for you

I have left my estates to you.

In case of the tenants abandoned their farmlands and went to another place, they were not in the position to ask the landlord for compensation for whatever they had left behind. ${ }^{33}$ It was during the eviction of Salaale Oromo to Baalee, Arssi and to some degree Wollaga specifically Horroo Guduruu and Jimmaa from their ancestral land, the Salaale sang a song in order to express their quuqaa (grievance) to the Shewan Amhara while praising Arssi, Baalee and probably others. When they were ready to migrate, they sang as follows:

Birraa daraara hadaanii a flower is flowering during the spring

${ }^{28}$ Informant: Iraasuu; see also Assefa, p.299.

${ }^{29}$ Mebrete, p.29.

${ }^{30}$ Informants: Iraasuu, Nagaash, Shitaa'ee and Abarraa Tolaa.

${ }^{31}$ Informants: Galaanee Daadhii, Warqituu Dubaroo and Shawuu Boggalaa.

${ }^{32}$ Informants: Iraasuu Garaasu and Ibid.

${ }^{33}$ Informants: Ibid. 
Nagaatti yaa biyya abbaa koo

Osoo na bo'uu garaanii

Amdee yaa ilma mootii

Harkaa dhabni dawwee nama gooti

Boroborii qotuun akka midhaan ta'ufi

Hiyyessa daddarbun akka biyya ba'ufi

Yaa birillee safara daadhii

Lammiin ormaa gaafa rakko

Wagala taati

Lammiin ofii gaafa rakko

Kafana taati

Baale fi Arssiin gosuma kooti. ${ }^{34}$ good by our father's land

while I was crying from the bottom of my heart

You Amde, the son of prince

being poor makes a man fool

cultivating the land is to a get good harvest

exploiting poor is to leave his homeland

oh Birillee the measure of local beer (mead)

aliens in time of trouble is

very uncompassionate

one's own people is

one's safe haven in time of trouble

Arssi and Baalee are my own relatives.

To be sure, their internal migration to Arssi and Baalee has been repeatedly described in their songs. The above song indicates that the land hunger because of its being seized by Shewan Amhara and maladministration were the most decisive push factors for the massive movement of the Tulama Oromo to Arssi and Baalee. It was during that time that the Salaale articulated their grievances (quuqaa) as follows:

\author{
Warri badda Salaale \\ Qanbari isaa gurracha \\ Mofarii isa xaaxeesadha \\ Yaa damma too beenu Arssii Bunaa \\ Biyyi kuni ratessadha. ${ }^{35}$ \\ Kuulle dhale, \\ iyya-andaaqqoo \\ iyya-andaaqqoo gara boodaa \\ siifan dhabe! \\ Lafa Abbaa koo \\ Lafa Abbaa koo kan dhalootaa.$^{36}$
}

\author{
those in the highland of Salaale \\ their yoke is black \\ while their beam of plow is xaaxessa (tree) \\ you my honey let us go to Arssi \\ this country would make a foul out of people. \\ my cow, bore a calf \\ she bore a calf at daybreak on the road \\ toward late in the morning \\ I left my Father Land \\ because of you, neftagna! \\ my homeland where I was born.
}

\subsection{The place of Agarii Tullu in oral songs}

Agarii remembered a lot from his young age how the Salaale peoples were evicted. To the feudalists, Agarii was a man who had bad character, an elegant bandit, and a grave danger to their power and well-being. That is the reason Haile Selassie's security commands attempted to arrest him. Later, the government put a reward of vast farmland and firearms to anyone who could capture or kill Agarii. ${ }^{37}$ In order to arrest Agarii Tullu, Fitawrari Muluu Asanuu presented a request that if he and his followers got a firearm known as Dimotfor; they would capture him. ${ }^{38}$ At that time, the people of the area sang the following warning song to Muluu Asanuu:

\section{Afaan Oromoo}

Agarii Tulluu dalga kaachisaa Hin dhaqin yaa Muluu Agariin udaan nama nyaachisa Eelen kan sibiilaati Yeroon gali yaa muluu Agarii Tulluu dhirsa dhiirati. ${ }^{39}$

\section{Gloss}

Agari is galloping the horse in horizontal way don't confront, you Mulu Agarii will defecate you the best oven is metal oven (2) go to your home on time, you Mulu Agarii is the heroes of hero.

Like the above song shows, heroes are celebrated and their deeds retold as a role model through songs and folklore. Along with ashkaris like Burruusee, DabaleeTasammaa and others, Muluu started to search him in different districts

\footnotetext{
${ }^{34}$ Informants: Geergisoo and Kololaa Kabbe

${ }^{35}$ Biratu, p. 101.

${ }^{36}$ Aseffa, p.311; see also Mohammed Ademo, "Agarii Tullu: From Serfdom to Revered Oromo Hero", October 2, 2013 , no page is given.

${ }^{37}$ Mohammed Ademo.

${ }^{38}$ Informants: Habtamuu Sanbataa, Tolasaa Irranaa and Abarra Tolaa.

${ }^{39}$ Informants: Ibid.
} 
of Kuyyuu, Hidhabu Abootee, Giraar Jaarsoo, Degam,Yaayyaa Gullallee and probably other. Some days later Shaalaqa Agari Tullu and Fitawrari Muluu Asanuu encountered in Lemman Sillaasee district and began to fire one other. At this, some of the Fitawrari Muluu Asanu's partisans were killed and others were wounded while the rests were exhausted. ${ }^{40}$ In that regard, the Salaale peasant sang a song to the force of Muluu Asanuu as follows:

\section{Afaan Oromoo}

Muluu rabbitu baasee

Dabalee Gurrarran yaasee

Burrusee dheeffatu baasee

Qawwwee Awraajjaa gachisiise

Yaa Agarii yaa abba bubbee

Situ albaase Muluu mataa shurrubbee.

\section{Gloss}

God saved the life of Muluu

Dabalee narrowly survived from Agarii's bullet

Burruusee run away

throwing the rifle of Awraja

Agarii, you are like wind speed

From the above song, one can simply see that Agarii openly resisted the landlords in Salaale particularly in the areas like Dagam, and Kuyyuu. Agarii could not continue his resistance in Salaale and escaped to Wallaga. The song below, attributed to Agarii, a soon as he marched to Wallaga, Naqamtee.

\section{Afaan Oromoo}

Tushaa fooyi

Wal argaa

Lubbun nama techiistu

Agarii Tulluu bu'e Wallaga

Agariin ta'et tokkosaa

Ergan biyya koo dhabee

Naqaamte taa'een ol tokkosa

Mogee keessa naanna'ii

Koo yaa Agarii koo yaa Agarii

Silaa of harkaa qabdaa

Immahonidhan (M1) itti waqarii

Adaammin hin qaxxaluu

Yoo damee dameen qaxxale malee

Agariin hin qabamu

Wallaga bu'eet qabame malee

Tumaalessi holaadha nan dhala jedhet

dhala dadhabee

Agaari ilmi Tulluu Wallaga bu'eet gala dadhabee. ${ }^{42}$

\section{Gloss}

how it could be possible to spine rope

while you are in danger

to save his life

Agari escaped to Wollega

Agari technique of gunfire is sitting

for I lost my homeland

Naqamtee is now my launching base to fight back

you Agarii, wander throughout Mogor

come, come Agarii

you have armed $\mathrm{M} 1$ rifle

and make assault on your enemy

Adaamii cannot be regenerated one's cut

unless its offshoot is regenerated

Agarii could not be captured

if he did not escape to Wollega,

Sheep makes an attempt to have offspring

but it cannot.

Agarii, the son of Tulluu went to Wollega, but was captured.

As Ethiopian News Agence (Addis Zemen) preserved in the IES and oral sources confirmed that Agarii who instigated the Salaale farmers to stand up for their rights and challenge the feudal lords eventually hanged in 1970. He was hanged in a broad day light in the town of Dagam along with his two brothers. ${ }^{43}$ Assefa Tefara has collected songs regarding one of the brothers of Agarii, whose name was Jimaa Tullu. The song below, accredited to Agarii, shows that Jima was executed without any serious involvement in violent banditry like Agarii, and to some extent, like Hirko:

Afaan Oromoo
Salaale calleessanii
Qamadii Salaale calleessanii
Kan anaaf Hirkoo tolee
Koodee koo Jimaa maaf balleessani

\section{Afaan Oromoo}

Qamadii Salaale calleessani

Koodee koo Jimaa maaf balleessani

\section{Gloss}

Salaale people give the yield to wind threshed and winnowed Salaale wheat. they might as well hang Hirko and me but what wrong did Jima do?and hanged

\footnotetext{
${ }^{40}$ Informants: Ibid.

${ }^{41}$ Informants: Habtamu, Asaffaa Shaaroo Lammii and Damisee.

${ }^{42}$ Informants: Habtamuu and Adinoo Gaarradoo

${ }^{43}$ Ethiopian News Agencies “Ageri Tulu Siklet Teferadabat.”Adis Zaman,(Megabit 29,1962 E.C.); also informants: Habtamu Senbata and Shimalis Kabbee.
} 


$$
\text { (...jedhe Agariin yo fannisani). }{ }^{44} \quad \text { Agari said. }
$$

The three brothers were hanged on the same day in Hambiso, Dagam, in Salaale.

\subsection{The place of Assefa Shaaroo Lammii in Oral Songs}

Like Agarii Tulluu, Asaffa was the well-known hero from Salaale who became Shifta at the age of 25 years. Like Agarii Tulluu, he grew up as the son of gabbar giving labor service for the lords with his father Lammii Hata'uu. He knows the oppression and exploitation of the regime because he grew up under such conditions. Initially, in the year of 1955, Assafa fled away from Nyoke or Laga Harbuu, his original homeland to a place called Bakkalchoo and later to Holqa Shakakkee (Shakakkee cave) to escape and save his life from enemies that is landlord. Assafa had strong relations with the majority of Salaale people particularly with the people of Warra Jaarsoo and Kuyyuu districts, who loved and supported him. ${ }^{45}$

These people assisted him by providing essential information to him secretly. They also provided food and drinks for him at their both home and cave. The local people of the area recommended Agarii and Asaffaa Shaaroo Lammii not to loot, the property of innocent people in the whole Salaale with the exception of those who expropriated the Oromo land and subjugated the masses. Here is a word of warning from peoples:

\section{Afaan Oromoo}

Agarii yaa Abbaa tiksaa

Agarii Tullu yaa abbaa tiksaa

Abba Jobir hin xuqin

Inni hoolatuma isaa tiksaa. ${ }^{46}$

\section{Gloss}

Agarii, the defender of his territory

Agarii Tulluu, the defender of his border

do not fight Abbaa Jobir,

for he is very innocent.

Similarly, Lammii Hata'u, father of Assafa warns his son as follows:

\section{Afaan Oromoo}

Atobisiin laga hin buluu

Asee yaa korma koo

Yoo magaalaa taate malee

Gosti ofii nama hin kennuu

Asee yaa korma koo

Yoo alagaa taate malee

Minishiriin Baale bu'aa

Asee yaa korma koo

Gama ormaa dhisi hin xuqnuu

Asee yaa korma koo

Hojjetanneetuma bulla. ${ }^{47}$
Gloss

the station of the bus is not at river

you, Aseffaa my hero

unless it is in the town

ones tribe cannot betray his kin for bad

you Asee my brave

unless he is being alien

the car travels to Baalee

you Asee, my hero

don't robe the property of aliens

you Asee my hero

we eat only the fruit of sweat.

Along with being successful in some goals of his struggle against oppressive rules, he faced many challenges and problems. This challenge mainly resulted from local landlords who considered his struggle often as the main obstacle to their land lord policies. For instance, the problem he encountered was while he spent as a bandit. During that time, the local landlords of the area whose name was Sibaat Tuuraa tried to assassinate him by shooting a gun bullet against him and caused damage on his right leg. Another challenge that faced Asaffaa was while he was in prison. ${ }^{48}$ While he was in prison, his family highly suffered from inadequate food and threatened by the landlord. It was during that time his father sang a song as follows:

\section{Afaan Oromoo}

Asee Shaaroo Lammii

Nan qotamoo nan haramaa

Yookan qotii qallabadhuu

Yookan gosattin galadhuu

Ani tiyyaayyuu dadhabee. ${ }^{49}$

\section{Gloss}

you Ase Shaaroo lammii

I either plough or weeding?

you had better plough to feed your offspring

or else divides your offspring among your clans

I am unable to feed mine.

\footnotetext{
${ }^{44}$ Assefa, p, 377.

${ }^{45}$ Informant: Asaffaa Shaaroo Lammii.

${ }^{46}$ Informant: Biraanuu Tesammaa and Caaltuu Baloo.

${ }^{47}$ Informants: Dachaasaa and Ijaaraa.

${ }^{48}$ Informants: Assaffaa Shaaroo Lammii and Galaan.

${ }^{49}$ Ibid.
} 
During that time, the governor of Salaale was Dajjach Galataa Qorichoo. According to local informants, the major crimes punishable through Afarfaataa were animal theft, robbery, house burning, assault and sometimes murder. ${ }^{50}$ Likewise, the shanacha (shanee) were responsible to have the sense of hearing, argue, legally examine cases and finally gave judgments. ${ }^{51}$ However, social institutions, afrfaataa and shanee were not just a judicial procedure and became great obstacles to Assafa Shaaro Lammi. Whenever officials of the emperor loot bull and sheep, the mislane erroneously prosecute him as thief .Mostly afarfaataa held on either Sunday or Saturday. The Salaale rulers appointed mellkanya, chikashum and mislane to their administration. They were responsible for keeping peace and order in village. ${ }^{52}$

Dejjach Gelata Qorichoo who was appointed as governor of Selale later became unpopular, considered like blood sucking man and never gets satisfied. ${ }^{53}$ And he accused by the peoples of Selaalee for doing the act of corruption. ${ }^{54}$ In line with this, the peoples of Salale sang a song to show their dissatisfactions to him as follows:

\section{Afaan Oromoo}

Hin taane yaa Dajjaach Galataa

Guyyaa guyyaa

Shaneen sobeet kakataa

Halkan hoolata namaa qalataa

Hin tanee yaa Dajjach Galataa

Har'as hin taane

Yaa Dajjach Galataa

Barreengaddaa qaccee fo'attaa

Barana immoo

Boorsaa hodhattaa

Isin yaa shanii

Gaaddisa qoree teessanii

Maliif sobdanii namarra keessanii

Kan hatu silaa ijollee kessanii. ${ }^{55}$

The purpose of this song is being to portray the extent and form of the economic subjugation of peasants and shows the peasant poets song of protest and social critique about local official's confiscation of land, corruption, and wished the change or policy of the administration.

When the opposition became intense against the imperial rule, the local people sang as follows Afaan Oromoo

Gloss

Hin qotta moo

Hin loltaa yaa gabaree

Algawaraash lafa hiruu jammaree. ${ }^{56}$ you, Dajach Galataa, your system of governing is not right

during day light

Shanee falsely swears

the Shanee slaughters sheep throughout the night

you Dajjach Galataa, your system of governing is not right

your system of governing is not right

you Dajjach Galataa

last year, you fairly treated the people

but, this year,

yourself involved in embezzlement

you shanii

who seats under the shadow of tree

why you accused falsely the innocent people

while your children are involving in theft activities.

This shows how much the people of Salaale wished to see the downfall of the feudal system. It seems that conditions were ripe in the region under study to receive the revolution of 1974. Likewise, in Salaale, the students, who knew the realities of unequal economic growth, loudly repeated peasant anxieties about land dispossession and the problem of the peasant. It is said that the student of Fiichee high school motivated the demonstration of Salaale peasant in 1962 to the front of the Amde court. The unforgettable measurement taken by the student of Fiichee was the demonstration made in front of Amde court. At that time, the student crushed government car and killed the son of Amde Abara whose name was Mulgeta Amde. ${ }^{57}$

Laskitiin cite

plastic was cut

\footnotetext{
${ }^{50}$ Informants: Ibid.

${ }^{51}$ Alemaayehu Hailee, Gadaa System: The Politics of Tulama Oromo...,p.200.

${ }^{52}$ Informants: Iraasuu and Olaanaa.

53 informant:Melaku Tefara

${ }^{54}$ Adinow Beyene, "Yetekeberu ye Dajjachmach Galata Qoricho Achir Hiwot Tarik".no folder number and file number

${ }^{55}$ Informants: Birhanu Tasammaa and Galaan Yeshanew.

${ }^{56}$ Informants: Dachaasaa Waarii and Birhanu.

${ }^{57}$ Informants: Biraanuu and Warqituu Dubaroo.
} 
Karchaamallen qabaamu didee Yaa barataa Situ mala kana fidee. ${ }^{58}$ and the bus cannot be controlled

it is you, student

who brought this sort of opposition.

The monopolization of land by landlords, during the imperial era was not radically challenged until the year 1965 . The state thereby effectively abolished the feudal traditional institutions of rist and gult, and took over the control to distribute access to land through Peasant Associations (PA). ${ }^{59}$ It was during that time in Salaale to show how the 1975 revolution considerably influenced the livelihood condition of landlords, peasant shows their past grievance through sang a song against them and praised the Derg regime as follows:

Afaan Oromoo

Darguu qoobiin saleenii

Abbaa Lafaa nyaatte sareenii

Darguu yaa daraggamaa

Loolan malee

Lafti hin argamaa. ${ }^{60}$

\section{Gloss}

you Darguu who hat crown plate

the dog scoff the landlord

you Darguu who squeeze the landlord

unless revolt

\section{Salaale Awraja as follows:}

Afaan Oromoo

Yaa galabaa shamaamee

Situ gamaa addaataa

Yaa intala balabaataa

Situ daaraa fakkaataa. ${ }^{61}$ how it could be possible to control to access to land.

Gloss

oh! the straw of wheat

is white from distant

you the daughter of landlord,

you seems like ash.

After Darg came to power, all things were changed due to land proclamation of 1975. Some few Balabats turned in to shiftas (local outlaws) and fought for a time being. Regardless of their resistance, landlords were demolished. Muluu Asanuu who was the representative of Salaale Oromoo tirelessly fought against the Derg regime. This was because before the Derg regime came to power, Mulu had a political power position. ${ }^{62}$ For instance, according to oral informants and various archival sources, Muluu elected as a member of parliament to represent the Salaale peoples with a candidate symbol of tiger representation. ${ }^{63}$

What is important to note here is that Muluu had been playing an important role since he elected as a parliament member. This makes him struggle against the military regime (Derg). Initially, the Worada governor peacefully asked him by sending the elders like Warquu Dabale, Dabale Korma, Zawde Arado, Waqtola Balcha and Adugna Robi together with seventeen milishas as arbitrator. The failure to surrender Muluu Asanuu peacefully prompted the Derg to use forces. It is said that the frequent violence in Darro goes back to the time of Gooshuu Gissilla, the great grandson of Muluu. He and his ancestor's firm resistance and strength remembered well in tradition as follows:

\section{Afaan Oromoo}

Ya mishingaa gammoojjii

Maali midhaanni hin biililee

Warri Muluu Asanuu

Jamaran waan isaanii

Maali zariin hin jiillee. ${ }^{64}$

\section{Gloss}

oh, the lowland sorghum,

what a grain that never buds!

Muluu Asanuu's folks,

they began once again (banditry)

what a folk that never pauses!.

The Ilamu clan played a vital role in capturing and giving essential information about Mulu because he killed them and confiscated their properties during and after Italian occupation for they participated in giving essential

\footnotetext{
${ }^{58}$ Informants:Geergisoo and Fayyisaa.

${ }^{59}$ Wibke Crewett, Ayalew Bogale and Benedikt Korf, "Land Tenure in Ethiopia: Continuity and Change, Shifting Rulers and The Quest for State Control”, in CAPRi Working Paper”, No. 91, (Washington, 2008), p.14.

${ }^{60}$ Informants: Galaanee Daadhii and Shawuu Boggalaa.

${ }^{61}$ Alemseged Debele,p.75.

${ }^{62}$ Informants: Kabbe Gissila and Mammoo Balachoo.

${ }^{63}$ Informant: Mammo Balacho; see also archive accessed from National Library and Archive agency (NALA), folder number 17.1.3.20, file number 17.1.3.21.06.

${ }^{64}$ Assefa, p.343.
} 
information to the Italians. Finally, the Darg's force was able to reach the destination where Muluu Asanuu was living together with his daughter, Kababush. In relation to this, Mulu Asanu prodused the following song of regret;

Afaan Oromoo

Illaammuu illee nan ajjeesee

Haco ammoo maalan balleessee

Domoftorii gadi guuree

Abbaa fi ilmaan natti duulee

Hin agarree poolisiitee

Warxaba keessan ciciibsee

Shimala keessattan dhiise

Ana dibbeetu na kiyyeessee $2 x$

Intala too yaa kabbabush

Harki mirgaa dhahamnaan

Harki bitaa mirga hin taatu

Beenuu gali yaa Mariidoo koo

Ilmi intalaa ilma hin taatu

Yaa barbareeyaa binnaanyii

Qe'een kan Getoo Gichooti

Abdaarii keenya hin gadhiifnu

Jedhe Mulu Abba Giraanyi

Baxana yaa Shifarraa koo

Osoo wal bira Jiraannee

Midhaan boqoo tokko waliin nyaannee. ${ }^{65}$

\section{Gloss}

Even I killed the Ilamu [clan]

Also what I made a crime to Haco[clan]

Collected the rifles to me

Poured to me with father and son

do you saw what I made your police officers

I killed them at the field

I absconded in shimala[a kind of trees]

It is Dibe [place] which exposed me

you Kababush my daughter $2 \mathrm{x}$

If the right hand wounded

the left hand never be the right one

you Marido the son of kababush go to your home

the son of daughter never be once son

Oh barbare Oh binanyi, a pepper flour dust

should we abandon Geto Gicho's home,

we never leave our abdaarii, sacred site,

Said Mulu Abba Giraanyi

Sorry, Shifera, the son of my brother

it was better if we were together

And fed small spot of food.

In addition to the Illamu clan, Alamayyoo was responsible for the capturing of Muluu Asanuu. It was during that time Muluu Asanu cursed Alamayyoo as follows:

\section{Afaan Oromoo}

Yaa Alamaayoo yaa baara

Barat goodhee maalan aaraa

Ya Alamaayitee

Ya Alamaayyoo Komaando,

Darroo Goshu nama hin baasu

Quba shaniin hari faandoo. ${ }^{66}$

Ani harkaa dhahamnaani

Tufaa Urjee macca ilaalee

Marid Aboote ilaalee

Jedhe rumiichi ijoollee Salaale. ${ }^{67}$

\section{Gloss}

You Alamayo the black man

I do not angry what times made

Oh, Alamaayo

you Alamaayyoo of Komaando,

Darro Goshu will not let you

make it clear cow dung in your five fingers.

while I was shouted on my arms

Tufaa Urjee forwards to Maccaa

And Marid forwards to Aboote

said the great man of Salaale.

Finally, he was brought to Garba Guracha town and was hanged publically. Thus on August 26, 1977, he was executed in front of the police station of Garba Guracha town.

Including Mulu Asanu, the Derg Regime killed high officials like Damissee Sagguu and Amdee Abarraa. Even though, Amdee Abarraa had been killed, the people still recall him in their songs as follows:

Afaan Oromoo

Jorroo qallaa dheedee

Qamaxxee laggaaraa

Marmaaramii ciisii yaa Amdee Abarraa. ${ }^{68}$

\section{Gloss}

the bull has feed

the grass lying on the waterway

You Amde Abara a cruel man, you got your final consequences

\footnotetext{
${ }^{65}$ Informants: Masqala Naggasaa, Abarraa, Biraanuu, Chenalow Asaffaa

${ }^{66}$ Informants: Ijaaraa, Dachaasaa and Dobocee Tuuraa.

${ }^{67}$ Informants:Ibid.

${ }^{68}$ Informants: Kololaa and Dobocee.
} 
Here it is better to note that that the Ethiopian "revolution" abolished the chauvinistic land holding system of Abyssinian feudal lords in the region under study.

\section{Conclusion and Recommendation:-}

\subsection{Conclusion}

The preceding discussion attempted to present historical oral songs and poems in the cultural resistance of Salaale Oromo in response to the economic exploitation and political subjugation of peasant by past regimes. The peasantsong expresses the Salaale grievance (quuqaa) against the local state representatives or officials of babalat, who "confiscated" his land after measuring it with a "Qaalad." By employing various genres of Oromoo oral poetry, the peasants of Salaale voice either impressions, grievances, protest, or support towards the state's agrarian policies, the local officials, and peasants. Songs of anger, opposition and suffering are common today in Salaale work songs, religious songs, and other songs implicitly communicating grief, dissatisfaction, and grievance. Currently, people in the rural area are become modernized and youngsters are getting access to modem education. Because of this, the new generations in their quest of knowledge and entertainment would be more inclined to reading books than listening to oral tradition. This trend has its own setback in limiting the number of people who possess oral songs and poetry. Therefore, to understand this national wealth and contribute towards its preservation, these kinds of studies are very important. By conducting research every time, one could contribute to retaining the wits, beliefs, and artistic works of a given community.

\subsection{Recommendations}

A society cannot be fully understood without its song. The very important point worth consideration is the fear that this oral antique would one day in the future probably cease to exist. Unless these oral treasures are preserved (recorded along with their present collective feelings, they may be unnoticed, or may totally be lost in the near future. Oral historical song and the "Weelluu" poetry reflect the style life of the traditional man, order of the day. In order to treat Salaale Oromo oral songs in its own right, our focus of attention should be on the established cultural traditions and historical experiences, together with those aspects of the social and political life of the Oromo that are the most helpful sources of our inspiration and techniques. The peasants' poetic responses to diverse past politics and to an often-abusive local administration should be studied and be appropriately considered in the state's future.

\section{Bibliography:-}

Thesis, Dissertation And Others Unpublished Documents

1. Alemseged Debele.2010. “A History of KuyyuWorada, 1936-1991”.MA. Thesis, History, Addis Ababa University.

2. Assefa Tefara.2013. "Heroes and Heretics: Performing Nationalism in Ethiopia Cushitic Salale Oromo in Northeast Africa". Indiana University, also available at ET h n o e c o 1 o g y. c o m.

3. AssefaTefera. 2015. "Ethnography of Resistance Poetics: Power and Authority in Salale Oromo Folklore." PhD. Dissertation, Folklore, Indiana University.

4. Biratu Kenei.2010.“A History of Oromo in and Around Finfinne (Addis Ababa)From Ca 1860-1974”,M.A. Thesis, History ,Addis Ababa University.

5. Dechasa Abebe.2015. "A Socio-Economic History of North Shewa, Ethiopia (1880s-1935)”.PhD, History, University of South Africa.

6. Mohammed Ademo 2013. "Agarii Tullu: From Serfdom to Revered Oromo Hero".

7. Wakene Frew. 1973. "The Family of Ras Darge and the Church in Salale 1870-1941", BA. Senior essay, Haile Sillaasee I University.

8. Workineh Kelbessa. 2001. "Traditional Oromo Attitudes towards the Environment an Argument for Environmentally Sound Development”, Social Science Research Report, Series - No. 19, Addis Ababa.

9. Alamayehu Haile.2009.Trans Dereje Hinaw, Gada System: The Politics of Tulama Oromo. Finfinne.

10. Arnesen, Odd Eirik. 1996. "The Becoming of Place: A Tulama Oromo Region in North Shoa". In Baxter, P.T.W., J. Hultin and A. Triulzi (eds). Being and Becoming Oromo: Historical and Anthropological Enquires. Uppsala.

11. Levine, Donald.1965. Wax and Gold: Tradition and Innovation in Ethiopian Culture.Chicago. 